\title{
DEVELOPMENT OF MANGROVE ECO-LITERACY STORYTELLING AS ENVIRONMENTAL EDUCATION LEARNING MEDIA FOR COASTAL CHILDREN IN BANTEN
}

\author{
Novi Utami Rosyid \\ Universitas Negeri Jakarta \\ E-mail: noviutamir_pklh17s2@mahasiswa.unj.ac.id
}

\begin{abstract}
One of the ecological problems on the Serang Coast is the degradation of mangrove ecosystems. Coastal communities suffer various losses due to damage to mangrove ecosystems. Mangrove degradation is triggered by the people's ignorance in utilizing mangrove ecosystems in a sustainable manner. for this reason, preventive solutions through environmental education are needed to increase the understanding of coastal communities about importance of the mangrove ecosystems through eco-literacy. Eco-literacy is environmental education approach to increase the ecological awareness of the community and create an environmental balance. This study aims to create and develop mangrove eco-literacy storytelling as learning media of environmental education for coastal children at SDN Lontar 2 -Serang. The research method used Research and Development by Borg and Gall (2008). The result of this study was learning media for the mangrove eco-literacy storytelling which has been through feasibility testing and field trials. The feasibility testing resulted $83.34 \%$ with a very good category. Field trials showed that there was a significant effect with the pretest and post-test based on the t-test 0.02 $<p=0.05$ which means that users of mangrove eco-literacy storytelling influences to increase of mangrove eco-literacy students. The conclusions show that eco-literacy of mangrove storytelling media is very feasible to use for the learning process and mangrove eco-literacy storytelling is proven to be able to improve the ability of eco-literacy mangroves of students in environmental theme learning at SDN Lontar 2 - Serang.
\end{abstract}

Keywords: Eco-literacy; Mangrove; Storytelling

\section{A. INTRODUCTION}

Mangrove ecosystem degradation has affected the coastal community in Serang - Banten in many sectors such as environmental problem, economic problem, and also social problem. Mangrove ecosystem degradation caused of abrasion in some of coastal areas in Serang - Banten. According to data from the Ministry of Environment and Forestry (2017), Area of Coastal Serang has lost 300 hectares of land due to abrasion. In addition, the degradation of mangrove ecosystems in the Serang Banten coastal area occurs because there is no protection for disaster mitigation.

Viewed from the physical aspect, mangrove have a role as protectors of coastal areas from wind, currents and waves from the sea, and also acts as a fortress from the influence of flooding from the mainland. In addition, the roots 
of mangrove species are also able to act as a trap for sediments and at the same time deposit sediments, which means they can also protect seagrass ecosystems and coral reefs from the dangers of siltation (Gholami, 2016). Mangroves have an important role in the protection of coastal areas, especially on the coast of Serang which has high potential for disasters so that their existence must remain sustainable (Alimuna, 2017).

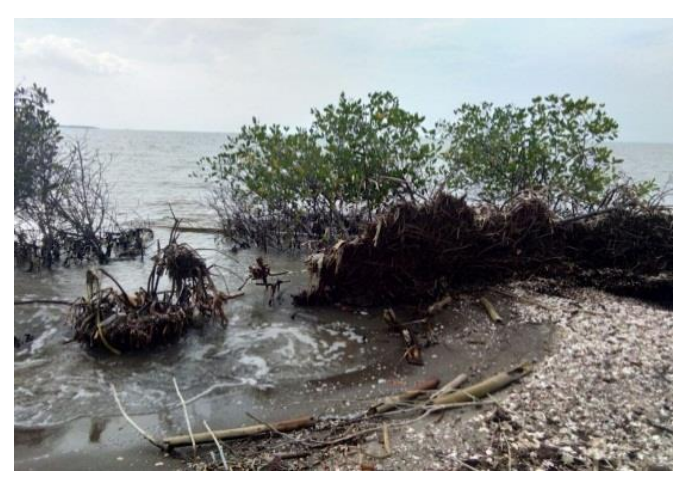

Figure 1. Mangrove Ecosystem Damage on the Serang Coast

Various environmental problems that occur if analyzed deeper are actually caused by humans themselves. The majority of coastal communities live on the poverty line because of lack of understanding of the management natural resources in coastal areas in a sustainable manner (Alimuna, 2017). Poor environmental awareness makes coastal communities do not understand the procedures for managing potential natural resources properly for decent economic resilience which actually causes pollution and environmental degradation (Cecep, 2016). Solutions through curative actions like physical development such as building breakwaters, making embankments and installing tsunami detection devices to prevent abrasion and tsunamis are very important, but sustainable solutions are needed through preventive actions by giving the community an understanding about the conservation of sustainable mangrove ecosystems through education (Kusmana, 2015). Education is an effective means of raising awareness of environmental preservation (Rusmawan, 2017). The best solution to overcome the low environmental awareness of coastal communities is through environmental education.

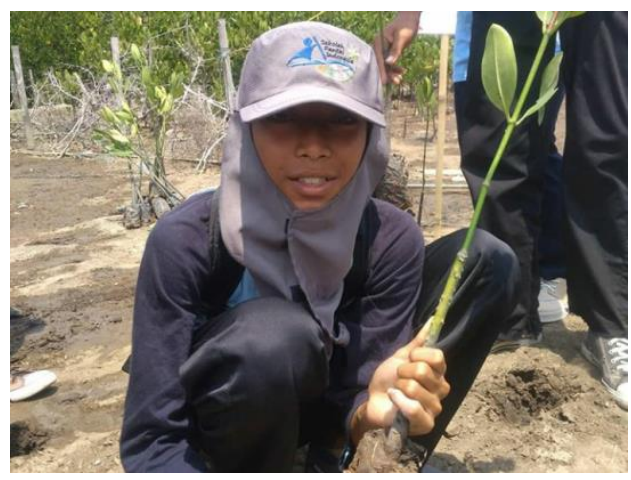

Figure 2. Coastal Student Planting Mangrove

Childhood is an important period for developing self-concept and sensitivity to become responsible citizens. Therefore, it is very important 
to gain insight in terms of approach, schools must help young people to be more sensitive to the environment, be more informed about the environment and further improve their skills in solving environmental problems (Hadzigeorgiou \& Judson, 2017). To increase environmental awareness it is necessary to develop "ecological literacy" or "eco-literacy" as an effective approach in the implementation of environmental education in elementary schools by instilling an ideal ecological situation in elementary school children (Sapanca \& Etmagusti, 2012).

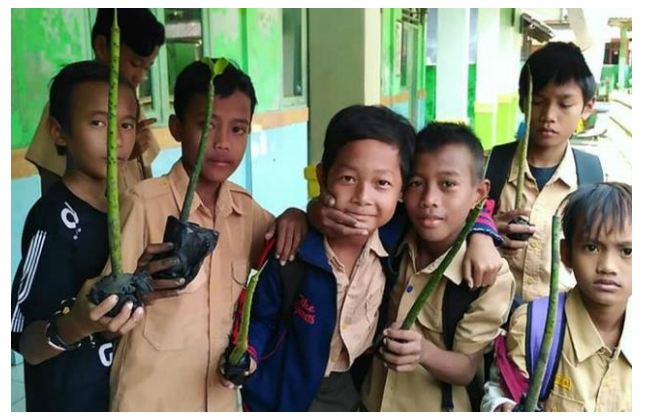

Figure 3. Costal Student Learning to Plant Seed of Mangrove

Eco-literacy comes from the words eco and literacy. Eco is an ecology which means the study of the interrelationships between humans and the environment. Literacy means literate, skill, understanding or conscious. Eco-literacy seeks to introduce and renew people's understanding of the importance of global ecological awareness, in order to create a balance between community needs and the ability of the earth to sustain it (Locke, Russo, \& Montoya, 2013). Eco-literacy is ecological relationships understanding and internalizing that are sustainable in nature and for transferring sustainable lifestyles this goes to everyday life (Capra, 2015).

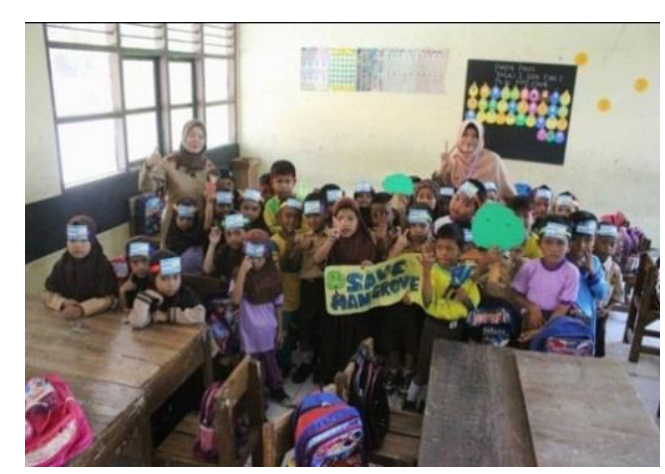

Figure 4. Teaching about Mangrove Conservation in Elementary School

Eco-literacy has three levels. The first level of eco-literacy is for students to recognize basic environmental terms and provide definitions of the meaning of the environment according to them. The second level of eco-literacy is the ability to use environmental knowledge and concepts to formulate positions on specific environmental questions. and evaluating information, choosing alternatives and taking action on various environmental problems (Muliana, Maryani, \& Somantri, 2017). 


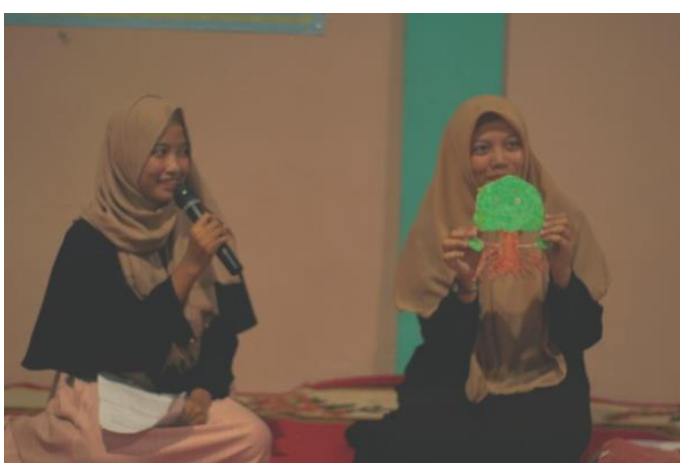

Figure 5. Eco-literacy with Storytelling about Mangrove

Eco-literacy has eco-pedagogical and ethno-pedagogical aspects which include the values of local wisdom in folklore for classroom learning activities. Local wisdom can be explored by incorporating stories about the surrounding community into the development process lessons (Supriatna, 2016). One of the learning media that is able to explore the ability of eco-literacy through local wisdombased stories is a storytelling. Based on research (Yulianti et al., 2014), it is known that storytelling can develop environmentally-conscious character of conservation for young children. Through a storytelling that tells the story of mangroves, children will get knowledge about mangroves in a fun way so as to enhance their eco-literacy abilities.

According to the results of preresearch observations at SDN Lontar 2, which is located on the coast of Serang, it is found that the learning media used as facilitators in the learning of Natural Science themes are still limited to textbooks and worksheets. Learning methods are still dominated by lectures. There is no learning media for mangrove eco-literacy storytelling in SDN Lontar 2 Serang for coastal children learning environmental themes. It takes a learning media for mangrove eco-literacy in the form of picture story books by raising the local wisdom of mangrove stories on the coast of Serang that is in accordance with the elementary school curriculum and has an evaluation for students' ecoliteracy in learning.

Based on this background, it is important to conduct research into the development of mangrove eco-literacy storytelling for coastal children in Serang - Banten. Hopefully, with the availability of learning media in the form of a mangrove eco-literacy storytelling that meets the needs of schools and curriculum, Serang coastal children will get environmental education in formal schools that are in accordance with the surrounding conditions so that they are educated and enlightened about the importance of mangrove ecosystems for the lives of coastal communities, especially in Serang - Banten. 


\section{B. MATERIALS AND METHODS}

In this learning media

The field trial phase carried out on development research, the writer refers to the (Borg, W. R \& Gall, 2003) model development research guidelines in the order of research as follows:

1. Analyze the needs and characteristics of students (determine the goals of the program or product to be developed

2. Formulate instructional objectives with typical operations

3. Formulate detailed material points that support the achievement of objectives

4. Develop a measure of success

5. Writing media scripts

6. Hold tests and revisions

Procedural steps in the research and media development include descriptive, evaluative, and experimental methods. Concept map of the steps of media development according to Borg \& Gall (2003) as follows:

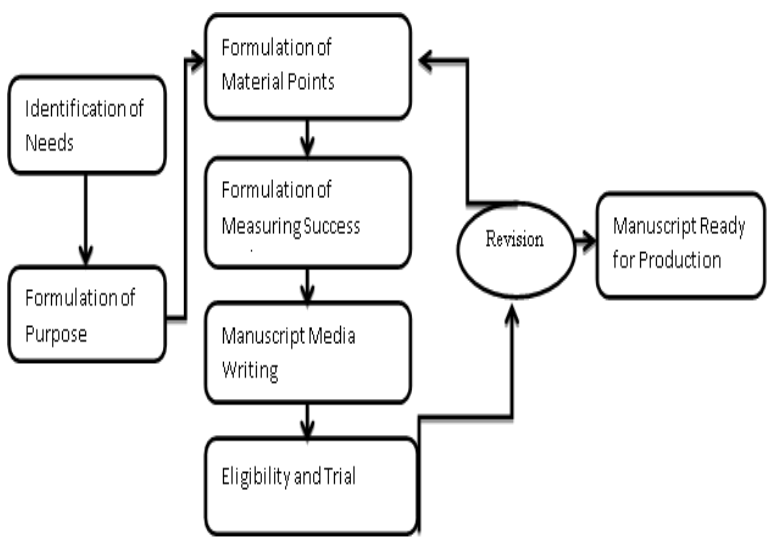

Figure 6. Borg and Gall Development Model Design 


\section{Data Analysis Techniques}

The analysis used in this research development has three techniques including learning content analysis, descriptive analysis, analysis of test results.

a) Learning Content Analysis

This analysis is carried out by formulating learning objectives that are adjusted to the competency standards and basic competencies to compile the developed learning media. The results of the analysis are then used as material for the development of mangrove ecoliteracy storytelling learning media.

b) Descriptive Analysis

This analysis was conducted at the time of the trial, data collected from the open questionnaire assessment and closed assessment questionnaire to provide criticism, suggestions and input improvements. The results of this descriptive analysis are used to determine the level of accuracy, effectiveness and attractiveness of the development products in the form of learning media in the form of mangrove ecoliteracy storytelling. Symbolic data will be analyzed logically and meaningfully, in processing research data using this technique is done by describing all opinions, suggestions, and responses from the validator. While the data in the form of numbers will be analyzed with a percentage, following the formula:

$$
\mathrm{P}=\frac{\sum X}{\sum X i} \mathrm{x} 100 \%
$$

Information:

P: Feasibility percentage (sought)

$\Sigma X$ : The total number of respondents' answers in 1 item

$\Sigma X i$ : The highest total number of answer scores in 1 item

The basis and guidelines for determining the level of validity as well as the basis for decision making to revise learning media use conservation scale of achievement levels, because in the assessment required achievement standards (scores) and adjusted to the specified categories according (Arikunto, 1998). Following the achievement qualification table:

Table 1. Scale of Achievement Levels

\begin{tabular}{|c|c|l|}
\hline $\begin{array}{c}\text { Score } \\
\text { Range }\end{array}$ & Criteria & Information \\
\hline $75-100 \%$ & Good & $\begin{array}{l}\text { Very decent, } \\
\text { no need } \\
\text { revised }\end{array}$ \\
\hline $50-74 \%$ & Pretty Good & $\begin{array}{l}\text { Decent, need } \\
\text { to revise }\end{array}$ \\
\hline $25-49 \%$ & Poorly & $\begin{array}{l}\text { Inadequate, } \\
\text { needs to be } \\
\text { revised }\end{array}$ \\
\hline $0-24 \%$ & Not Good & $\begin{array}{l}\text { not feasible, } \\
\text { needs a total } \\
\text { revision }\end{array}$ \\
\hline
\end{tabular}

Source: Arikunto, 1998 
Based on the above assessment, the instructional media is said to be valid if it fulfills the requirements for achieving 61-100 of all elements contained in the design expert questionnaire, content experts in instructional media, class teacher learning experts and students in grade 3 at SDN Lontar 2. In this development learning media must meet the criteria valid. Therefore, a revision is made if the learning media does not meet the valid criteria.

c) Analysis of Test Results

Data analysis of the results of tests conducted to measure the level of comparison of student learning outcomes, in field trials conducted using experiments by comparing the conditions before and after using a new teaching method (before-after). The following explanation relates to the experimental model before after:
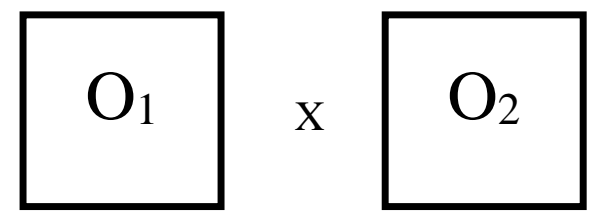

Figure 8. Design Experimental (Before-After)

Information:

$\mathrm{O} 1=$ Value before treatment

$\mathrm{O} 2=$ Value after treatment

$\mathrm{X}=$ Treatment
Field trial data were collected using a questionnaire and achievement test (achievement test). Field trial data is then collected using a pre-test and a post-test in order to find out the comparison of the results of the field trial group's learning outcomes, namely third grade students of SDN Lontar 2 before using development products and after using development products learning media of mangrove eco-literacy storytelling. The analysis used to determine the mean pre-test and posttest with the following formula:

$$
\text { Mean }==\frac{\sum X}{N}
$$

Information:

Mean: Average

$\Sigma X$ : Number of pretest posttest scores $\mathrm{N}$ : Number of samples

Based on the analysis using the mean (average) pre-test and post-test, then paired t-test is used to strengthen the data. The following formula is used in a significance level of $0.5 \%$ as follows:

$$
\mathrm{t}=\frac{D}{\frac{\sqrt{d^{2}}}{N(N-1)}}
$$

Information:

t: T-test

D: Diferrent (X2-X1)

d2: Variance

$\mathrm{N}$ : Number of Samples 
d) Hypothesis

The research hypotheses for this development are as follows:

Ha: There is a significant difference in the mangrove eco-literacy of students in the III SDN Lontar 2 class before and after using the learning media of the Mangrove Eco-literacy storytelling.

Ho: There was no significant difference in the mangrove eco-literacy ability of students in grade III at Lontar2 Elementary School before and after using the learning media of the Mangrove Eco-literacy storytelling.

\section{RESULTS AND DISCUSSION}

\section{Result Product of The Development} Mangrove Eco-Literacy Storytelling

\section{Book}

Learning media that have been developed are in the form of a mangrove eco-literacy storytelling book This learning media can be reviewed from several components that can be seen. Further details are as follows:

\section{1) Front Page / Cover}

The front page of this learning media in the form of a mangrove ecoliteracy storytelling book is titled "Strong Rhizopora". The cover of mangrove eco-literacy storytelling book features the main character named Rhizopora with the characteristic of a Baduy-style batik hat which is one of the local wisdoms of Banten Province.

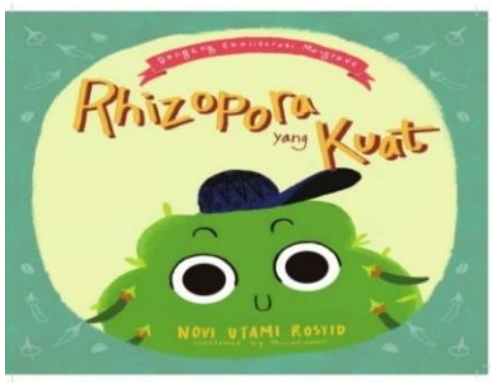

Figure 8. Cover of the Mangrove Eco-literacy Storytelling Book

2) Learning Objectives

This section contains details of the competence students must master in learning.

\section{3) Introductory Page}

Introduction to the mangrove eco-literacy storytelling learning media contains a general definition of mangrove ecosystems and the background of the events that make the background of the creation of mangrove eco-literacy storytelling for coastal children of Serang.

\section{4) Figure Introduction}

The introduction of the characters contains pictures of the characters who play a role in the story "Rhizopora Strong" in the book of mangrove eco-literacy storytelling.

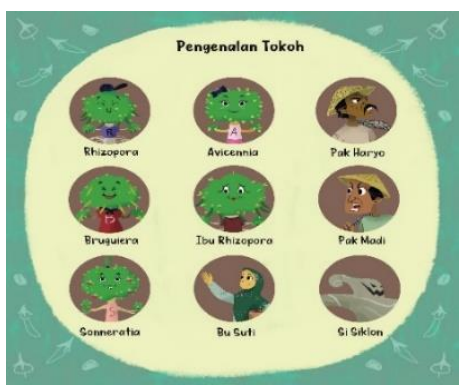

Figure 9. Figure Introduction 
The types of figures in the mangrove eco-literacy storytelling are as follows:

- The protagonist who is the main character is Rhizopora

- The antagonist is Si Cyclone

- Tritagonist figures, Mr. Madi and Mrs. Suti

- Deutragonist figure, Mrs. Rhizo

- Foil figures are Avi, Brugu, and Sone and Mr. Haryo

\section{5) Main contents}

The main contents of the learning media of this mangrove eco-literacy storytelling contain the whole story entitled "Strong Rhizopora".

a) Orientation

In this orientation section contains the introduction of all the characters, introduction to the setting of place and time, as well as the introduction of problems or conflicts in the mangrove ecoliteracy storytelling. The correct background setting and the time when the four mangrove tree friends namely Rhizo, Avi, Sone, and Brugu play in around the coastal area of the Serang Coast then Mrs. Suti came to take the fruit from the mangrove trees.

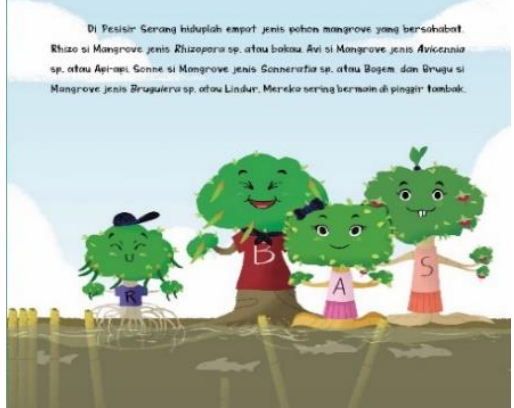

Figure 10. Figure Orientation Section, Background, and Place

The problem orientation occurs when the three friends of Rhizo namely Avi, Sone, and Brugu are hostile to Rhizo because Rhizo cannot produce fruit that is beneficial to residents and Rhizo Root which is considered different and oddly shaped. Rhizo also became sad because Mr. Haryo had to cut Rhizo's roots because he was considered that Rhizo have damaged the pond.

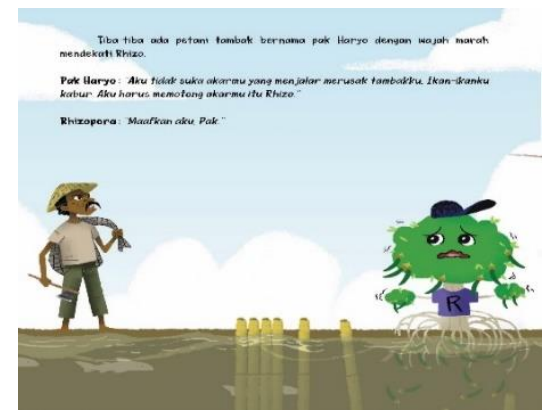

Figure 11. The Problem Orientation Section 
b) Complications

The complications part is the climax or the peak of the problem in the story experienced and felt by the characters. The complication part occurs when the Cyclone who is an evil high wave wants to destroy the coastal residents of the coast but was successfully stopped by Mrs. Rhizopora and the Rhizopora trees were grown with their root strength to break the waves The cyclone's evil became a small ripple and the coastal residents survived.

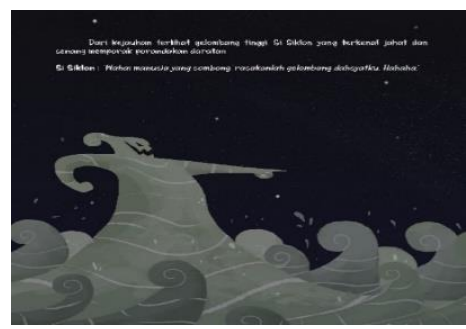

Figure 12. Complications Section

c) Resolution

Resolution is part of solving the problems experienced and felt by the characters in the mangrove eco-literacy storytelling. The coastal residents survived thanks to the strong roots of the Rhizopora tree dan say sorry to Rhizo for his actions. The coastal community finally realized that all mangrove trees have benefits including Rhizo and its species the

Rhizopora.

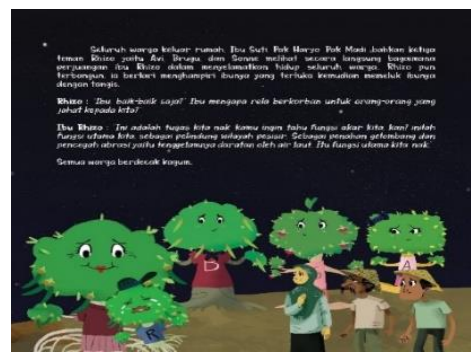

Figure 13. Resolution Section

d) Koda

The koda is the final part of the story that contains the messages and mandates contained in the fable story itself. The code from the mangrove ecoliteration fable explains that mangroves have important functions and roles so we must preserve them.

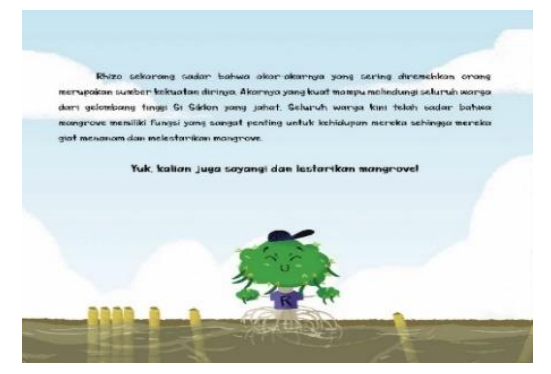

Figure 14. Koda Section

e) Evaluation

The evaluation section contains exercises that measure students' mangrove ecoliteration including knowledge about mangroves, mangrove utilization and management skills, and attitudes towards mangrove conservation. 
Feasibility Test of Mangrove Ecoliteracy Storytelling

The feasibility test of mangrove ecoliteracy storytelling in this research consists of two kinds, namely quantitative data and qualitative data. The data was obtained through two stages of assessment, namely expert validation and field testing.

a. Expert Validation

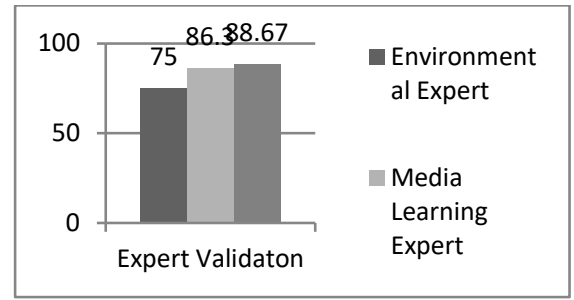

Figure 15. Student Mangrove Eco-literacy

The results of experts evaluation the learning media of mangrove ecoliteracy storytelling have a high level of eligibility based on material experts obtained a validity percentage of $75 \%$, media design experts obtained a validity percentage of $86.3 \%$, and learning experts obtained a validity percentage of $88.67 \%$ so that the average value of experts evaluation rating of $83.34 \%$ is in the very good category. In generally, it can be concluded that this product has fulfilled the requirements and deserves further testing (field trials / effectiveness tests). b. Field Test

Mangrove eco-literacy storytelling media that has been field tested by involving 30 third grade students of SDN Lontar 2 who study environmental theme materials based on the local wisdom of the Serang coast, the mangrove ecosystem, showed a positive contribution in increasing the ability of students' mangrove eco-literacy. Analysis of different tests on the results of the pretest and posttest showed very significant differences with a significance value of $0.02<p=0.05$. The results of the analysis illustrate that students have increased the ability of mangrove eco-literacy after learning by using the learning media of mangrove eco-literacy storytelling. Improvement of students' mangrove eco-literacy abilities can be seen as follows:

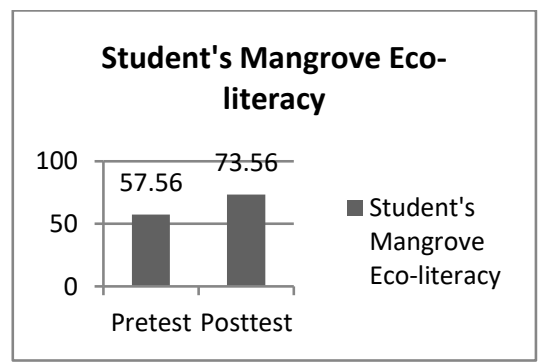

Figure 16. Student Mangrove Ecoliteracy

Referring to the results of the statistical analysis the results of the pretest and posttest illustrate the 
increase in the ability of students' ecoliteracy after learning by using a mangrove eco-literacy storytelling. Atmosphere, images, settings, or major themes related to the environment Through storytelling, language literacy can be maximally developed. One of them is language literacy that involves the environment as a medium called eco-literacy. Ecoliteracy is the process of increasing knowledge, skills, attitudes and behavior based on ecology. The three indicators of eco-literacy can be improved through the learning of mangrove eco-literacy storytelling in a fun way. Increased students' mangrove eco-literacy can be observed through figure 17 as follows:

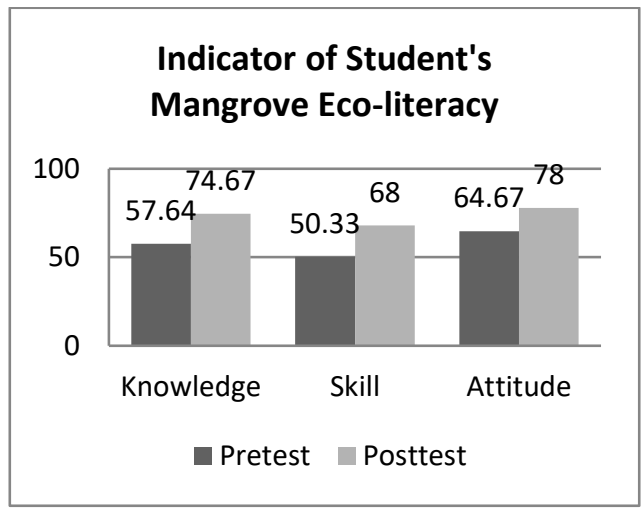

Figure 17. Student's Indicator Mangrove Eco-literacy

Based on the results of mangrove eco-literacy research students using the mangrove eco-literacy storytelling learning media can be observed that an increase in each indicator of mangrove eco-literacy includes mangrove knowledge, mangrove conservation skills, and caring attitudes towards mangrove conservation.

Mangrove eco-literacy storytelling can increase knowledge in this case is knowledge about mangroves because storytelling affected children's intelligence. Repetition of stories in fairy tales favored by children (reps) is very useful for practicing memory, thinking power, and analysis power of children (Hadzigeorgiou \& Skoumios, 2013b). Storytelling is a series of spoken words that are used as a means of communication aids, with a load of positive values, and moral messages that will be embedded in children's memories so that it is a way to instill knowledge about a concept effectively for children (Mitchell, 2015). Through the mangrove eco-literacy storytelling, the concept of mangrove knowledge contained in the story from the understanding, types, and functions and roles of mangroves can be conveyed without being patronizing and in a fun way.

Mangrove eco-literacy storytelling is also positively 
correlated to the improvement of students' skills in mangrove conservation. This is due to the nature of storytelling that can train children's imagination (Hadzigeorgiou \& Skoumios, 2013a). Imagination can develop children's thinking and creativity without being limited by reality and daily reality. The use of learning media mangrove eco-literacy storytelling can develop mangrove conservation skills because in the story unconsciously implanted about various information about how mangroves can grow and develop, where mangrove habitat, and the characteristics of mangroves that is a representation of the characterization, setting, and flow in the story of mangrove eco-literacy so that it becomes a provision to develop skills in mangrove conservation.

Mangrove eco-literacy storytelling can improve students' attitudes of care towards mangrove conservation. This is due to storytelling characters that contain advice. A storytelling is a way of giving advice to children so that children want to listen and according to what is said by parents, teachers, and friends ( $\operatorname{Lin} \& \mathrm{Li}, 2018$ ). Storytelling becomes one of the alternative learning media to instill noble values in children. With storytelling character, learning of mangrove is more interesting and attractive. Storytelling is also a significant instrument in internalizing the cultural values of the pure soul. Storytelling is able to instill many things that are educative, constructive and inspiring in the mindset of children. Through Storytelling media, children's awareness of the importance of caring for the environment can grow. As a medium to give the values of life, storytelling is "saying without patronizing". In listening to the of mangrove ecoliteracy storytelling, children can enjoy while understanding the concept of mangroves and the values to preserve mangroves in the story without needing to be told explicitly. Storytellers only tell stories without the need to emphasize or discuss themselves about the moral values contained in the story. This is what is referred to as the subtle transfer of values and ethics to children. The process of instilling such values and ethics is actually more easily implemented by children. By learning with mangrove eco-literacy storytelling, a caring attitude to preserve mangroves can also be instilled in students with fun. 


\section{CONCLUSIONS}

This development research resulted in a product in the form of a learning of mangrove eco-literacy storytelling in the form of a picture book with a high level of eligibility, obtaining an average validation of material experts, media, and learning experts at 83.32 and included in the excellent category. Based on the research results, learning media of mangrove ecoliteracy storytelling was also proven to be able to improve the ability of eco-literacy of third grade students of SDN Lontar 2, Serang - Banten with a high significance value of $0.02<\mathrm{p}=0.05$ so that $\mathrm{H} 0$ was rejected, and $\mathrm{Ha}$ was accepted, which means the use of mangrove eco-literacy storytelling has an effect on increasing mangrove eco-literacy in Lontar 2 Elementary School students.

\section{E. REFERENCES}

Alimuna, W. (2017). PENGARUH AKTIVITAS MASYARAKAT TERHADAP KERUSAKAN HUTAN MANGROVE DI RAROWATU UTARA , BOMBANA SULAWESI TENGGARA. Universitas Gajah Mada.

Arikunto, S. (1998). PROSEDUR PENELITIAN: Suatu Pendekatan Praktek (11th ed.). Jakarta: Rhineka Cipta.

Borg, W. R \& Gall, M. D. (2003). Educational Research: An Introduction (7th ed.). New York: LONGMAN.

Capra, F. (2015). Cultivating 20 Years of
Ecoliteracy. Newyork.

Cecep, K. (2016). Integrated Sustainable Mangrove Forest Management. Journal of Natural Resources and Environmental Management, 5(1), 16.

https://doi.org/10.19081/jpsl.2015.5.

2.1

Gholami, D. M. (2016). An Overview on Role of Mangroves in Mitigating Coastal Disasters (With Special Focus on Tsunamis, Floods and Cyclones) mangrove View project Wildfire Prediction View project.

Hadzigeorgiou, Y., \& Judson, G. (2017). Toward More Effective Storytelling for Raising Environmental Awareness in Young Students The Potential Role of Storytelling for Raising Environmental Awareness. Journal of Advances in Education Research, 2(1), 12-18.

Hadzigeorgiou, Y., \& Skoumios, M. (2013a). The development of environmental awareness through school science: Problems and possibilities. International Journal of Environmental \& Science Education, 8(2013), 405-426. https://doi.org/10.12973/ijese.2013.2 $12 \mathrm{a}$

Hadzigeorgiou, Y., \& Skoumios, M. (2013b). The development of environmental awareness through school science: Problems and possibilities. International Journal of Environmental and Science Education, $\quad 8(3), \quad 405-426$. https://doi.org/10.12973/ijese.2013.2 $12 \mathrm{a}$

Lin, C., \& Li, Y. (2018). Protecting Life on Land and Below Water: Using Storytelling to Promote Undergraduate Students 'Attitudes toward Animals. Journal Sustainability, $\quad 10,1-15$. 
https://doi.org/10.3390/su10072479

Locke, S., Russo, R. O., \& Montoya, C. (2013). Environmental Education and Education for Sustainable Development. Journal of Sustainability Education, 4(January), 569-584. https://doi.org/10.1007/978-94-0173368-7_39

Mitchell, H. J. (2015). Knowledge sharingthe value of story telling. International Journal of Organisational Behaviour, 9(5), 632-641.

Muliana, A., Maryani, E., \& Somantri, L. (2017). Ecoliteracy Level of Student Teachers ( Study toward Students of Universitas Syiah Kuala Banda Aceh ) Ecoliteracy Level of Student Teachers ( Study toward Students of Universitas Syiah Kuala Banda Aceh ). In IOP Conf. Series: Earth and Environmental Science (Ed.), 1st UPI International Geography Seminar. Bandung: IOP Publishing.
Sapanca, P. L. Y., \& Etmagusti. (2012). Efektivitas Ekoliterasi Dalam Meningkatkan Pengetahuan, Sikap Dan Perilaku Masyarakat Mengenai Education For Sustainable Development Berbasis Tanaman Pangan Lokal (Studi Kasus Di Kecamatan Bangli). AGRIMETA: JURNAL PERTANIAN BERBASIS KESEIMBANGAN EKOSISTEM, 1, 1-13.

Supriatna, N. (2016, October). Local Wisdom In Constructing Students' Ecoliteracy Through Ethnopedagogy And Ecopedagogy.

https://doi.org/10.2991/icse-15.2016.28

Yulianti, D., Rida, ), Dewanti, S. S., Diana, ), Fisika, J., Matematika, F., ... Fakultas, P. (2014). PENGEMBANGAN KARAKTER PEDULI LINGKUNGAN ANAK USIA DINI MELALUI BUKU CERITA BERMUATAN SAINS BERWAWASAN KONSERVASI. In Jurnal Penelitian Pendidikan (Vol. 31). 